\title{
Optimisation of the Food Estate Program through Cash Waqf to Achieve Food Sovereignty in Indonesia
}

\author{
Denizar Abdurrahman Mi'raj, S.EI. \\ Postgraduate School \\ Universitas Airlangga \\ Surabaya, Indonesia \\ denizarabdurrahmanmiraj@gmail.com
}

\author{
Dr. Muhammad Nafik Hadi Ryandono, SE., M,Si. \\ Department of Islamic Economics \\ Universitas Airlangga \\ Surabaya, Indonesia \\ muhammadnafik@feb.unair.ac.id
}

\begin{abstract}
Food Estate is a government program with the concept of integrated food production development covering agriculture, plantations and animal husbandry located in a large land area. In simple terms, the concept of Food Estate is like a food industry village. Running this program requires a large capital, so the government has opened up opportunities for investment locations for the private sector to achieve efficiency, effectiveness and added value of the products that are produced. The presence of a wave of private investment in the food estate program was, however, not able to raise the welfare of the tenant farmers. Agricultural land tenure by investors makes the farmers only labourers. It is the investors who are getting all of the benefits in the food estate program. To overcome this problem, it is necessary to look for other capital alternatives. By using library research in this study, cash waqf has been put forward to be used as the capital alternative. Through cash waqf, assets of waqf in the form of empty lands can be processed into agricultural land. Cash waqf can also be in the form of productive loans for farmers and agricultural investment. The large potential of cash waqf in Indonesia is expected to replace the role of private investors.
\end{abstract}

Keywords—cash waqf; food estate; food sovereignty

\section{INTRODUCTION}

Today, agriculture is regarded as backward and is beginning to be abandoned. Farmland in Indonesia, especially in urban areas, is little by little being sold. The fields of rice fields and fields of function have begun to shift and turned into elite residential complexes or industrial estates. In fact, Indonesia should have great potential in this field. The potential of agriculture and forestry can be seen from the amount of biodiversity that is $15.3 \%$ of the total of $5,131,100$ biodiversity worldwide (second only to Brazil) [1]. The wetlands area is stable and increased by a total of $8,114.829$ hectares in 2014 [2], to be regarded as a world paradise by a qadhi 'from Syria in the 50s, named Shaykh Ali AthThanthawi. He once made a visit to Indonesia (Jakarta). The visit is listed in his book "Shuwar min al-Syarqi fil Indunisiyya" as follows:

\author{
Ummi Muthia Fathy, S.EI. \\ Department of Islamic Economics \\ Universitas Airlangga \\ Surabaya, Indonesia \\ muthiaalfatih@gmail.com \\ Prof. Drs. Tjiptohadi Sawarjuwono, M.Ec., Ph.D. \\ Postgraduate School \\ Universitas Airlangga \\ Surabaya, Indonesia \\ tjiptohadi@feb.unair.ac.id
}

"Heaven in this world is not located in Sham country, not Lebanon, nor Switzerland, but heaven in this world is located in Java. Whoever ever saw the land of Java, surely he will justify what I say. "

The agricultural sector plays an important role in the economy of a developing country, including Indonesia. The provision of accessible food by every household at an affordable price is essential for the creation of food security, poverty alleviation and economic development.

Various steps have been taken by the government to achieve food sovereignty, such as a food estate program. Food Estate is a government program with the concept of integrated food production development covering agriculture, plantations and animal husbandry located in a large land area. In simple terms, the concept of a food estate is like a food industry village. The management is done with the concept of industry based on science, capital, and modern organisational modern management.

The concept of developing a large-scale integrated food estate has been assessed to contribute significantly to the national food reserves. Given the scale of this project, not just the Ministry of Agriculture is involved. The Ministry of Forestry is in charge of preparing the land, the Ministry of SOEs is in charge of preparing the appropriate SOEs to manage it, and the Ministry of Public Works fixes infrastructure such as new paddy fields, reservoirs and irrigation. The Ministry of Agriculture, in addition to coordination, is also responsible for agricultural technology.

The presence of a wave of private investment in the food estate program is not able to raise the welfare of the tenant farmers. Agricultural land tenure by the investor makes the farmers only labourers. The person who benefits in the food estate program is the investor. To overcome this problem, there needs to be other capital alternatives from waqf of money or also called cash waqf. 


\section{A. Food Estate}

A food estate is the large-scale production of food crops. This definition strongly suggests that a food estate-style farming culture is reserved for owners of capital or large corporations [3]. Given the scale of this project, the Ministry of Agriculture is not the only one involved. The Ministry of Forestry is in charge of preparing the land, the Ministry of SOEs is in charge of preparing the appropriate SOEs to manage it, and the Ministry of Public Works is there to improve the infrastructure such as new rice fields, reservoirs and irrigation. The Ministry of Agriculture, in addition to coordination, is also responsible for agricultural technology.

In the concept of food estate issued R \& D Ministry of Agriculture, farmers will find it difficult to control the production land. The reason for this is their weak capital. Because the project is large scale, the government requires the owner of the means of production to come from both from private and red plate companies. While farmers, smallholders and small farmers certainly cannot resist the power of capital and the size of the land owned by the concession holders (forest concessions).

\section{B. The Implementation Food Estate in Indonesia}

In Indonesia, food estate programs have been implemented in Merauke - West Papua, Bulungan - East Kalimantan and Kubu Raya and Pontianak - West Kalimantan. The implementation of food estates in Indonesia is included in the Masterplan Program of Acceleration and Expansion of Indonesian Economic Development (MP3EI) 2011-2025.

One of the main projects of MP3EI is the Merauke Integrated Food and Energy Estate (MIFEE) in southern Papua - a giant scheme that clears land and damages the traditional livelihoods of indigenous Malind and other indigenous groups in the southern part of Papua.

In MP3EI, Kubu Raya was placed as a Food Estate to build Indonesia's food security. It is a major development involving SOEs and the State Budget. The Minister of Agriculture has issued Decree No. 491 / RC.110 / X / 2011 related to this area [4].

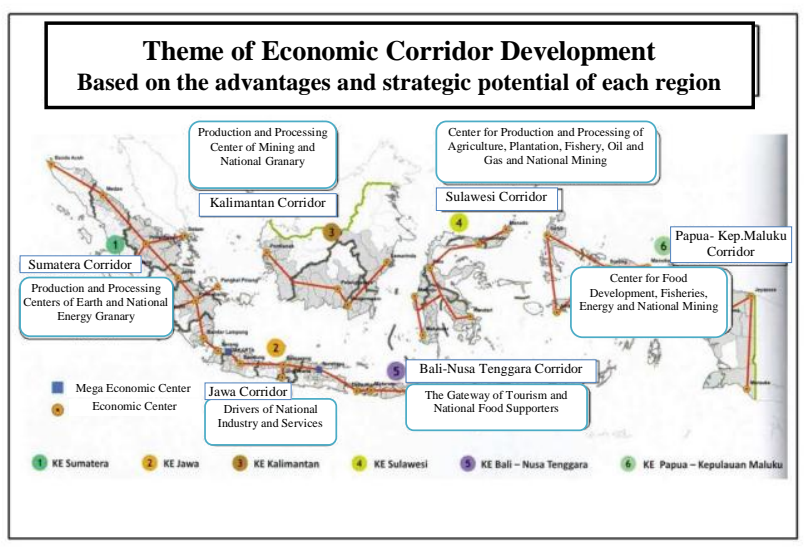

Source: MP3EI Handbook (2012)

Figure 1. Theme of Economic Corridor Development

"Based on the wide area of Food Estate is divided into 2 (two) models: (1) Food Estate on a wide scale with very limited infrastructure conditions. Example of Merauke
Integrated Food and Energy Estate (MIFEE). Need to build adequate basic infrastructure either by the government (central / regional) and private support. (2). Medium-scale Food Estate with an area of about 3,000 - 5,000 Ha, with relatively adequate infrastructure. Example: Bulungan, Sambas, Kuburaya, Pontianak, Singkawang. In its strategy, the development and management of food estate involves local governments, central government, SOEs and farmers so that the form of PEN and BUMP " [5].

\section{Cash Waqf}

Generally, waqf comes in the form of property such as land and buildings, but nowadays it has been widely agreed by scholars that one of the forms of waqf can be in the form of cash. In general, the definition of cash waqf is the delivery of waqf assets in the form of cash that is non-transferable and frozen for anything other than public interest, which does not reduce or eliminate the principal amount (essential substance of waqf).

Cash waqf is a kind of endowment given by individuals and Muslim institutions where the fund will be used for poverty alleviation and improving the welfare of the poor. Technically, this cash waqf certificate can be managed by a separate social investment agency as well as Social Investment Bank Limited (SIBL) in Bangladesh. It can also be one of the products / institutions of sharia banking. Bank Muamalat Malaysia Berhad (BMMB) and PerbadananWakaf Selangor (PWS) have collaborated towards implementing the cash waqf scheme in Malaysia and it has proven to be the most famous and important tool for Islamic banking [6].

\section{The Potential of Cash Waqf in Indonesia}

Economically, cash waqf has the big potential to be developed in Indonesia, because with this cash waqf model, the reach and mobilisation will be much more even in the midst of society compared with the traditional waqf model in the form of fixed assets which is usually done by relatively capable families only. Waqf fund management as an investment tool is attractive, because the benefits will be enjoyed by the community everywhere (both local, regional and international).

The potential of cash waqf in Indonesia is considerable. Musthafa Edwin Nasution said that the potential waqf money that can be collected from the 10 million strong Muslim population is about Rp 3 trillion per year. The same statement was also delivered by Dian Masyita Telaga. The potential endowments of money that can be collected in Indonesia reached $\mathrm{Rp} 7.2$ trillion in a year with the assumption that the Muslim population of 20 million set aside Rp 1,000 per day or Rp 30,000 per month. So much potential has been conceived, and the management being diligent, trustworthy, professional and full of commitment will certainly be able to release the dependence of Indonesia on foreign debts that have been mounted up to now. With the management of cash waqf, Indonesia no longer needs to owe money to multilateral creditor institutions as a source of development financing, as the cash waqf funds themselves have been able to complement state revenue in addition to taxes, zakat and other income. Through various studies, the role of cash waqf is not in the release of the economic dependence of the multilateral creditor institutions alone. It is also capable of being a component of economic growth. 


\section{E. Food Sovereignty}

Food sovereignty is the right of every nation and every people to produce food independently and the right to establish agricultural, livestock and fishery systems without any subordination of the international market forces.

Food sovereignty is a prerequisite of food security. It is impossible to create food security if a nation and its people have no sovereignty over the process of food production and consumption. It is therefore imperative for every nation to have the right to decide on the food that they choose and the agricultural policy that it undertakes, in relation to local food production capacity at the local level and trade at the regional level.

\section{RESEARCH METHOD}

This study uses a descriptive qualitative approach with the library research method which almost exhausted the data that is theoretical and the documentation that existed in the library. Library research is done by reviewing the ideas of experts, existing concepts, rules that bind the objects of science and professional views. This study uses the Qur'an and hadith as the main source and some literature in the form of books and previous research journals.

\section{RESULT AND DISCUSSION}

\section{A. Food Estate Impact for Food Sovereignty in Indonesia}

Indonesia faces severe challenges that include how to get out of the food crisis due to the reduced productive agricultural land area in Java and the high rate of population growth. With various considerations to bear in mind, the government considers that the food estate program can be an option to overcome the food problems. This program is a breakthrough production mode that is attempting to be introduced and implemented in order to pursue the increasing need of national food which is then expected to realise food security in Indonesia. Food products that to be produced through the mode of production (food estate), are the following among others: rice (rice), corn, soybeans, sugar (sugar cane) and cattle farms [7].

The urgency of the food estate is motivated by several issues at national level: population growth, increasing food demand, climate change and depleting oil / fuel reserves. Therefore, efforts to increase production through the expansion of the food estate area with the target of the creation of food production centres are expected to be a driver of the regional economy. The objectives of the food estate are (1) to improve the welfare of the people, (2) to save and generate state income, (3) to accelerate the development of equality, (4) to create employment and business opportunities and (5) to increase regional economic growth and the national economy. It is expected that with the existence of the Food Estate, then we will be able to feed Indonesia and feed the world.

In the implementation of Food Estate in Indonesia, one thing that must be considered is that the program should be able to support other government programs, especially those mandated in the Presidential Regulation No. 22 of 2009 on the Acceleration of Food Consumption Diversification. Experts need to assess the commodities that need to be cultivated in the food estate agronomically, technologically and socio- economically. While we may be facing problems related to national rice production, the food estate should not be directed to rice production alone. We hope that through this food estate, the diversity of food consumption can be more quickly achieved by trying to make the food estate produce various foodstuffs that can be processed into raw materials for the manufacture of various foods that can support food diversification.

Related to this matter, the location must be equipped with post-harvest handling facilities and raw food processing facilities for changing the raw materials into semi-finished materials or finished materials at once within the port or means of transportation for the distribution of products from the food estate. With the existence of the food estate, local food production along with processing technology should be encouraged to be able to meet not only the local needs but other regional needs as well. Thus, it will help to create a more stable food security community.

In relation to the achievement of food sovereignty, the current food estate program has not achieved food security and food sovereignty. In fact, domestic crop production has decreased resulting in inadequate domestic demand. This has caused the government to import rice and soybeans.

The Central Bureau of Statistics (BPS) recorded the value of Indonesian rice imports in 2011, which reached USD 829 million or approximately Rp 7.04 trillion rupiah. This amount of money has been disbursed by the government to bring in 1.57 million tons of rice from Vietnam (892.9 thousand tons), Thailand (665.8 thousand tons), China (1,869 tons), India (1,146 tons), Pakistan (3.2 Thousand tons), and several other countries (3.2 thousand tons). BPS also recorded that soybean imports during 2011 reached 2.08 million tons with a value of US \$ 1.24 billion, which is much larger than the previous year which was only about one million tons [8].

The facts above reflect that the food estate program in Indonesia has not been able to make Indonesia as a country have food sovereignty and food security.

\section{B. Role of Cash Waqf in Food Estate Program in Indonesia}

Cash Waqf is the best solution as an alternative to capital in food estate. The cash waqf model is considered to be appropriate to provide a promising answer for realising social welfare and helping to overcome Indonesia's contemporary economic crisis, amidst the turmoil of intensive tax holiday policies to stimulate foreign capital inflows. Cash waqf has the great potential to be a source of endowment funding in order to avoid debt bondage and dependence on foreign countries. Cash waqf is very relevant to providing a mutual fund model through the mobilisation of a professionally managed fund that is trustworthy in its fund management amid doubts about the management of waqf funds and the anxiety of domestic investment crisis and capital flight syndrome.

Investments done in waqf funds can be done anywhere without state restrictions. This is expected to increase harmony between the rich and poor. The social welfare issue proposed by the discourse of cash waqf brings out the root of social problems, in the form of economic justice which fails to be manifested by conventional development theory (Capitalist and Marxist theory). In this case, cash waqf can also be applied in relation to the investment of food estate. 
Here is a step to optimise the cash waqf for food estate program in Indonesia:

1. Regulation of representation legislation.

Legislation concerning waqf before the birth of Law No. 41 of 2004, namely Government Regulation No. 28 of 1977 and Law No. 5 of 1960 on the basic rules of Agrarian Law, only regulates immovable waqf objects and is intended for more worship of mahdhah, such as mosques, Pesantren, cemetery and others. Due to the limited scope, the regulation of perwaqfan legislation is regulated so that the representatives can be empowered and developed more productively.

\section{Optimising Role of Indonesian Waqf Board}

In Indonesia, a waqf institution that specifically manages a waqf fund and has national potential is the Indonesian Waqf Board (BWI) that coordinates the existing nadzir-nadzir and independently manages the waqf property entrusted to it, especially cash waqf. The BWI function is expected to help in financing and in relation to the supervision of the nadzhir to be able to manage the waqf, especially cash waqf productively. For that, BWI requires competent human resources that are dedicated and have strong commitment to the development of waqf and understanding the problem of waqf.

3. Optimising the Law on Regional Autonomy and Local Regulations

Regional autonomy provides opportunities for the development and empowerment of both waqf and food estate programs. In addition, what each region requires is the presence of a regional vision oriented towards poverty alleviation through Islamic means.

If each region that has the resources that meet the requirements of the implementation of food estate can establish an agency perwaqfan through the Regional Regulation (Perda), then it is very possible that the program of the food estate can run without the need of investment from foreign companies.

\section{Establishing Business Partnerships}

The business partnership in the food estate program with the capital of cash waqf consists of all parties who assist in the running of this program, including the government, farmers union, sharia financial institutions, and the distributors of agricultural products from the food estate. In this case, no one party has the dominant role. All parties have a partnership relationship that is based on kinship.

\section{Issuance of Cash Waqf Certificate}

The cash waqf certificate is intended to be an instrument for empowering rich families in fostering social interactions as well as realising social welfare. In addition, a certificate of cash waqf can change old habits where waqf opportunities are only for the rich. Thus the certificate of cash waqf is expected to be a means for social reconstruction and development, where the majority of the population can participate in the food estate program.

\section{CONCLUSION}

Based on the data and discussion that has been done, some conclusions can be made as follows:
1. Pioneering food sovereignty in Indonesia is not easy, due to the high demand for food and the inadequate yields of food crops causing the Indonesian government to still importing some food commodities. This is coupled with low access to resources and productive assets to meet the needs of life, among others: science, information, technology, and capital.

2. The Food Estate Program is one of the efforts to achieve food sovereignty, but in its implementation, there needs to be strong control from the government if the capital comes from foreign investors so that the farmers do not become labourers in their own country. Alternative capital other than foreign parties can with cash waqf.

3. The management of waqf funds is the management of public funds that have the advantage of channelling funds in the form of financing, both investment financing and working capital participation.

\section{SUGGESTION}

The suggestions that can be conveyed through this paper are:

1. The government is expected to be able to handle the need for knowledge, information, technology and capital.

2. Ease of access in financing capital for farmers in the food estate program through cash waqf.

3. Building synergy between the government, cash waqf institutions, and farmers in the Food Estate Program through the management of cash waqf to achieve food sovereignty in Indonesia so that it is not just a discourse.

\section{References}

1] Bahtera, Eka, Terbesar Kedua di Dunia, Keanekaragaman Hayati Indonesia baru Tergarap 5\%. (Online). http://news.unpad.ac.id/?p=36173, 2013, accessed on July, 10th, 2017.

2] Badan Pusat Statistik, (Online), https://www.bps.go.id, accessed on July, 10th, 2017.

3] Sjaf, Sofyan. Food Estate dan Petakanya, (Online), http://sofyansjaf.staff.ipb.ac.id., 2010, acceessed on July, 10th, 2017.

4] News Report, Menko Perekonomian akan Kawal Food Estate di Kubu Raya, Kalimanatan Barat: Harian Equator, November 21st, 2011.

5] Rumusan Seminar Nasional Food Estate di Indonesia, 2010 http://fema.ipb.ac.id., accessed on July 9th, 2017.

6] Mokhtar, Farhanah Mohd., Sidin, Emira Mad. and Razak, Dzuljastri Abd., Operation of Cash Waqf in Malaysia and Its Limitations., Journal of Islamic Economics, Banking and Finance, Vol-11, No.4, Octo-Dec, 2015.

7] Rumusan Seminar Nasional Food Estate di Indonesia, 2010 http://fema.ipb.ac.id., accessed on July 9th, 2017.

8] Badan Pusat Statistik, (Online), https://www.bps.go.id, accessed on July, 10th, 2017. 